\title{
Developments
}

\section{Regulatory Convergence through the Back Door: TTIP's Regulatory Cooperation and the Future of Precaution in Europe}

\author{
By Marija BartI*
}

\begin{abstract}
This paper analyzes the possible impact of TTIP's so-called regulatory cooperation on the implementation of the precautionary principle in the EU. The European Commission argues that regulatory cooperation will not impinge on the application of the precautionary principle because, first, it does not change the legislative framework of precautionary legislation and, second, the right to regulate will be safeguarded by the TTIPs horizontal chapters. On the contrary, I argue in this paper, that these guarantees are insufficient. Given the methodological and institutional constraints presented by the TTIP's institutional design, in the long run, regulatory cooperation will undermine the precautionary approach to regulation in the $\mathrm{EU}$.
\end{abstract}

*Marija Bartl is Assistant Professor at a Faculty of Law, the University of Amsterdam. 


\section{A. Introduction}

This Article explores one of the core questions fueling the Transatlantic Trade and Investment Partnership (TIP) controversy: Whether, and to what extent, the MIP impacts the implementation of the precautionary principle (PP) in the EU. Despite widespread concerns in Europe about chlorinated chicken or hormone treated beef, the concept of precaution is curiously absent in the main textual proposals for the TTIP. The European Commission assures us that the PP will not be compromised, even potentially. First, the TTIP will include a general right of the state parties to regulate in the public interest. ${ }^{1}$ Second, as argued in the case of chemical regulation and REACH, ${ }^{2}$ the TTIP cannot change the legislative framework for regulation without parliamentary involvement ${ }^{3}$-and, thus, no race to the bottom should take place. Yet I argue that appearances in this case prove to be deceptive.

When considering the future of precaution in Europe, it is tempting to give prominence to the TTIP's sectoral rules or the horizontal chapters such as the Chapter on Sanitary and Phyto-sanitary measures. Yet, I will argue that, in a long run, it is the TTIP's Regulatory Cooperation (RC) that will have the most significant consequences for the future of precaution in the EU.

The RC presents a set of institutional arrangements designed to eliminate new and old behind-the-border barriers to trade. By creating institutional channels for the exchange of information, methods, and knowledge between regulators, it is believed that the thinking, and consequently the acting, of regulators across the Atlantic will converge. The decisions of the RC would also have no formal binding powers. Rather the RC would operate on a subtler level of the institutionally induced persuasion of regulators, as abetted by stakeholders, and at very early stages of regulatory process, far from parliamentary oversight.

I argue that in these early stages of the regulatory process, the RC will encroach on the operation of the PP in Europe. The most significant inroads are: a) the alignment of the use of science in regulation between the EU and the US, b) the exchange of economic assumptions and methods for cost-benefit analysis between the two trading partners, and

\footnotetext{
${ }^{1}$ See Textual Proposal of the European Commission for the Chapter on "Regulatory Cooperation" in TTIP, art. 1, para. 3 (March 21, 2016), http://trade.ec.europa.eu/doclib/docs/2016/march/tradoc_154377.pdf; Eur. Comm'n, TTIP Initial Provisions for CHAPTER on Regulatory Cooperation, art. 1, para. 3 (May 2015), http://trade.ec.europa.eu/doclib/docs/2015/february/tradoc_153120.pdf.

2 See Eur. Agency for Safety and Health Work Regulation No. 1907/2006, Dec. 182006 (EC) (concerning the Registration, Evaluation, Authorization and Restriction of Chemicals) [hereinafter REACH].

3 See Eur. Comm'n, Chemicals in TTIP-New Ideas for Working Together (Nov. 21, 2014), http://trade.ec.europa.eu/doclib/press/index.cfm?id=1204. The EU Chemicals Regulation REACH has been one of the main examples for how regulatory cooperation should operate within the framework of the TTIP.
} 
finally, c) international standardization. Furthermore, I suggest that the TTIP institutions themselves are designed such as to weaken, rather than sustain, the implementation of PP in the EU.

Before I embark on the analysis, two caveats are in order. First, because the TTIP negotiations have not been concluded yet, the analysis is based on provisional legal sources: The Commission's position papers ${ }^{4}$ and the recently leaked documents. ${ }^{5}$ Second, the analysis presented here takes these documents at their face value and predicts possible institutional dynamics in the emergent structures. Given that we lack sufficiently comparable arrangements elsewhere, the analysis of the institutional dynamics in the TTIP relies mainly on the assessment of incentives and strategies available to actors. ${ }^{6}$

The Article proceeds in the following way: I will commence by discussing the role of precautionary principle in Europe and various levels on which it operates, before turning to explore the three TTIP inroads into the implementation of the PP. I show that the RC's stress on the exchange of methodologies, the assumptions as to the use of science, and the evaluation of costs and benefits will facilitate the movement of the European regulatory practice closer to that of the US, while the support for international standardization will drive the EU to lower its standards. The final part of this paper explores how the TTIP institutionsbilateral exchange, the institutional mechanism and sectoral committees-present a framework that will enable a gradual break with the EU's precautionary approach.

\section{B. The Precautionary Principle in the EU}

According to the Commission's 2000 communication, the precautionary principle:

enables rapid response in the face of a possible danger to human, animal or plant health, or to protect the environment. In particular, where scientific data does not permit a complete evaluation of the risk, recourse to this principle may, for example, be used to stop distribution or order withdrawal from the market of products likely to be hazardous. ${ }^{7}$

\footnotetext{
${ }^{4}$ See Eur. Comm'n, Position Papers Regulatory Cooperation, (Feb. 10, 2015), http://ec.europa.eu/trade/policy/infocus/ttip/DocumENTS-and-events/index_en.htm\#eu-position.

${ }^{5}$ TTIP Leaks, GrEeNPEACE, https://ttip-leaks.org/ (last visited June 10, 2017, 4:15 PM).

${ }^{6}$ This is taking inspiration from the new institutionalisms in political science.

7 Eur. Comm'n, Communication: The Precautionary Principle (Feb. 2, 2000), http://ec.europa.eu/health/ph_determinants/environment/EMF/Conf24_26feb2003/belveze.pdf.
} 
The PP represents a regulatory approach toward uncertain, uncontainable, or uncontrollable risks of business activity or new technologies. ${ }^{8}$ Behind the principle lies the recognition that technological progress is not necessarily always harmless-for people or the environment. First, because much of technological progress in our societies is market driven, the choice of kinds of innovation pursued may not be always sensitive to public interest. Second, even with the best motives, the state of our knowledge does not allow us to understand all of the possible risks that new products and technologies can bring forward. And it is better to be safe than sorry, precautionary logic implies.

The PP is understood, and eventually operationalized, in several different ways. For example, Cass Sunstein's classification draws a distinction between a weak understanding - the right to act against uncertain yet potentially seriously harmful risks-and a strong understanding of the precautionary principle-the obligation to act in a precautionary manner in case of a serious threat. ${ }^{9}$ Lujan and Todt in their taxonomy of precaution develop another useful toolbox to classify the principle. The weakest, or "Risk Based Interpretation," usually distinguishes between scientific risk assessment and political risk management, maintaining still a rather Cartesian understanding of science. The median "Epistemological Limits Interpretation" recognizes the role of the risk assessment phase; but, it does not suggest that this exercise can be fully objective, or scientific. This approach intimates that we must take into account the epistemological limits of various scientific methodologies, and the inherent normativity of any scientific enterprise already in the risk assessment phase. Ultimately, science cannot tell us how to order our normative priorities. Finally, the most expansive interpretation of the PP is "Technology Selection Interpretation," which suggests that the role of the precautionary principle is pro-active: It should steer technological innovation in a desirable-green-direction. ${ }^{10}$

As operationalized in the EU, the precautionary principle probably belongs to the strong category, in Sunstein's framework. The EU has a constitutional obligation to act in a precautionary manner in case of risks to environment and health, ${ }^{11}$ and European courts

\footnotetext{
${ }^{8}$ See David Vogel, The Politics of Precaution: Regulating Health, Safety, and EnVironmental Risks in Europe AND the United States (Princeton 2012); James Hammit et Al., The Reality of PRECAution: Comparing Risk Regulation in the UNITED STATES AND EUROPE (Routledge 2013). The questions concerning the kind of risks covered by precautionary approach have animated a rather lively academic or political debate in recent years. Does precaution encompass the regulation protecting us from deer running across streets or terrorism, or is its main concern the uncertain risks of business activity? Depending on the response to this question, we may see the EU and the US as more or less precautionary-influencing also the conclusion of whether we need to be concerned about the TTIP or not. These two citations are the most important contributions here.

${ }^{9}$ See Cass Sunstein, Laws of Fear: Beyond the Precautionary Principle (2005).

${ }^{10}$ See José Luis Luján \& Oliver Todt, Precaution: A Taxonomy, 42 Soc. STUDIES SCI. 143 (2012).

${ }^{11}$ See Treaty on the Functioning of the European Union, Oct. 26, 2012, 2012 O.J. (C 326) art. 121.
} 
have played an important role in the enforcement of the principle. ${ }^{12}$ According to Lujan and Todt, the EU would belong to a modest, market-innovation friendly category. ${ }^{13}$

Examining the Commission's Communication on the PP, several elements stand out. First, a condition for the application of the PP is a sufficient degree of scientific certainty about its 'uncertainty.' Second, the authorities need to evaluate the risks of action and non-action and provide for the participation of stakeholders in the evaluation process. The authorities may decide to act if the level of risk is high-and they may do so through various measuresprohibiting certain products or activities is certainly not the only option. In terms of normative evaluation of measures to be taken, several principles are applicable: Nondiscrimination, proportionality, consistency, examination of costs and benefits, and the review of measures in the light of new scientific developments. Only in some cases, according to the Communication, the PP may require the reversal of burden of proof.

Perhaps the most famous example of the operationalization of the PP in the EU is the REACH regulation on chemicals. In the TTIP debate, REACH has fulfilled several purposes in the European Commission's rhetoric. It has been furnished as an example of untouchable regulation; according to the Commission, the differences with the US are such that we cannot seriously consider unifying the approaches. ${ }^{14}$ At the same time, this regulation has served to demonstrate how the RC could kick in in the implementation state of the regulatory process. ${ }^{15}$

Examining REACH, the practical operationalization of PP in the EU becomes clear: The distinction between the legislative framework on the one hand, and the implementation framework on the other hand. REACH presents a legislative framework, which outlines the action of both individuals and authorities in the management of chemicals in the EU market. First, REACH regulates the possibility for individuals to introduce chemicals into the market, through the process of registration of chemicals or through the more demanding process of authorization of chemicals. The most important feature of REACH is, in this regard, the reversal of the burden of proof. It is those who propose certain potentially harmful activities that have to justify the imposition of this risk on society. Second, REACH regulates the process in which authorities (the EU and the EU member states) evaluate whether certain

\footnotetext{
${ }^{12}$ Case T-521/14, Sweden v. Comm'n, ECLI:EU:T:2015:976 (2015). In one of the more recent decisions, the General Court has backed Sweden in its claim that the Commission's failure to prohibit certain endocrine disruptors in a time frame set by an EU regulation is a violation of EU law.

${ }^{13}$ See Marjolein B. A. van Asselt \& Ellen Vos, The Precautionary Principle and the Uncertainty Paradox, 9 J. RISK RESEARCH 313 (2006).

${ }^{14}$ Textual Proposal of the European Commission for the Chapter on "Regulatory Cooperation" in TTIP, art. 1 para. 3 (Mar. 21, 2016), http://trade.ec.europa.eu/doclib/docs/2016/march/tradoc_154377.pdf.

${ }^{15}$ See id.
} 
substances should be placed on a candidate list or in the annex of substances presenting a very high concern. ${ }^{16}$

Thus, the PP principle in REACH legislation is relevant at two different levels and two different points of time. First, it is relevant for the design of the legislative framework, which for instance incorporates reversal of the burden of proof in the process of registration and authorization of chemicals. Second, the PP is also relevant at the level of implementation, and at many later points of time, when authorities decide which particular chemicals should be designated as of a very high concern and, thus, subject to authorization procedure. It is foremost at the level of implementation when the three inroads gain importance.

\section{Three Modes of Impact}

The main argument of the European Commission that the RC will have no impact on PP stands on a claim that the RC will not interfere with the legislative process. Thus, it cannot change laws nor regulations, such as REACH, without standard legislative procedure. Yet, the same argument cannot be made at the level of implementation. For instance, in the case of $\mathrm{REACH}$, the implementation is left to regulators and the European Commission, outside of the direct oversight by parliamentary bodies. It is also at this level that the RC aims to operate and, if successful, re-shape the thinking of the EU and US regulators. It aims to do so through a shift to sounder science, the ways we do impact assessments-cost-benefit analysis-and finally, through international standardization.

\section{Sounder Science?}

We often think of science as the opposite of politics: Objective, neutral, and dispassionate. Yet the role of science in regulation has been more political than is generally assumed. ${ }^{17}$ The political clashes have concerned the vast grey zones, where science has no responseseither because there is no research, or scientific consensus, or where the questions are primarily the matters of value and political choice. ${ }^{18}$ What is relevant in the context of this paper is that the grey zones of science, that which is uncertain, has received a different legal treatment in the EU and the US. How much evidence should be provided and by whom? The questions of the burden of proof and standard of proof in the case of uncertainty are the core legal-political questions regarding the use of science in law-making. The response to

\footnotetext{
${ }^{16} \mathrm{REACH}$, supra note 2 .

17 See Sheila Jasanoff, The Fifth Branch: SCIEnCE AdVISERS AS PolicymaKers (2009) (distinguishing between regulatory science and innovative science).

${ }^{18}$ For instance, the way in which we decide on the acceptable level of risk.
} 
these questions foregrounds the different regulatory approaches on the two sides of the Atlantic. ${ }^{19}$

The starting position in the EU regulation has been that citizens have a right to clean environment, while the potential polluters must show that their products or activities are harmless to the environment or health. The US position has been just the opposite. On the other side of the Atlantic, it is the authorities who have to prove the harmfulness of certain products or activities before any eventual public action can be taken to curtail private autonomy. If scientific uncertainty is considered a cause for political action in the EU, "better safe than sorry", in the US, the same scientific uncertainty would be often considered as an impediment to progress and a reason not to act.

What is the position of the TTIP in this regard? The Commission's earliest position papers on $\mathrm{RC}$ have made science the sole legitimate ground for regulation. ${ }^{20}$ While this rhetoric has disappeared in the most recent position paper, the use of science will still receive considerable attention as the core justification for regulation. First and foremost, without any specific provision, the role of science will be imported partially from the OECD guidelines on good regulatory principles, ${ }^{21}$ and to a greater extent from the WTO context, where it has been at the core of struggles concerning phytosanitary measures. ${ }^{22}$ Second, the stress on the unification of scientific methodologies and assumptions tends to overlook the profoundly different normative assumptions that stand behind the two different ways in which science is used in the EU and the US.

The struggle over the use of science is likely to become an important political issue in the TTIP institutions, with consequences to the implementation of PP. Three points should be noted here. First, the desired approximation of regulatory solutions through aligning scientific methodologies and approaches is unlikely to take place without aligning the normative assumptions regarding the appropriate use of knowledge and science. Second, any such alignment with the US is likely to lead to the weakening of the EU precautionary approach, since the differences between the two jurisdictions are principled and normative. Third, as I discuss in the fourth part of this paper, this effect on the precautionary principle

\footnotetext{
${ }^{19}$ See Asselt \& Vos, supra note 13.

${ }^{20}$ See Marija Bartl \& Elaine Fahey, A Postnational Marketplace: Negotiating the Transatlantic Trade and Investment

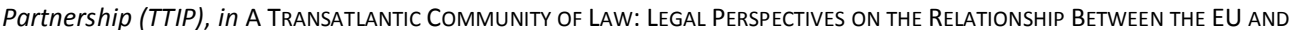
US LEGAL ORDERS 210 (Elaine Fahey \& Deirdre Curtin eds., 2014). This is not to claim that science is not a fundamental source of invaluable information in regulation; rather, I am concerned here mainly with the use of science, which has more to do with law's framework than the substantive merits of science.

21 See Organization for Economic Cooperation and DeVelopment, ReCommendation of the Council on Regulatory POLICY AND GOVERNANCE (2012), http://www.oecd.org/gov/regulatory-policy/49990817.pdf.

22 See Jacqueline Peel, Of Apples and Oranges (and Hormones in Beef): Science and the Standard of Reviewiln WTO Disputes Under the SPS Agreement, 61 INT'L \& COMP. L.Q. 2 (2012).
} 
may be aggravated if staged against an institutional background that sets ground rules unfavorable to the precautionary principle.

Another, perhaps subtler, effect of the TTIP on the role of science in risk regulation will concern the internal EU debate and critique regarding the proper scope of application of precautionary principle. The EU's approach as developed in the COM 2000 communication, but also within REACH, has been characterized by limiting the precautionary approach to so called "risk management phase". The internal critique of this approach holds that it does not take precaution seriously. ${ }^{23}$ First, the EU understanding of precaution does not ensure that the inherent normativity of knowledge is dealt with well in the regulatory process; for instance, by sufficiently stressing the need to ensure pluralism of methodological approaches as well as the diversity of assumptions that steer the scientific projects. A second important critique has been that the EU's approach is not sufficiently oriented toward promoting more desirable-greener-technological innovation. ${ }^{24}$

These critiques become even more salient with the TTIP. In order to curb regulatory differences between the EU and the US, the TTIP promotes the adoption of similar standards and methods. Thus, the need to approximate the EU and the US market will go directly against the need for the promotion of methodological pluralism and diversity, which as those critiques suggest is the core requirement for ensuring the epistemic validity of science, minimizing various errors and biases in scientific knowledge. In addition, by enlarging the market in which those harmonized methods should be applied, the TTIP would reproduce eventual bias across this larger regulatory space.

Furthermore, the TIP's main objective toremove barriers to trade and investment, rather than any other objective such as sustainable or green economy, may create an additional hurdle to the promotion of regulation aimed at supporting and motivating the introduction of green technologies: One of the primary goals of more robust versions of precautionary principle. ${ }^{25}$ This hurdle is not, thus far, compensated by other provisions of the emerging TTIP agreement, which would offer a substitute for supporting green technological development across the Atlantic. Sustainable development chapter in the TTIP does a very poor job in this regard; It lacks horizontally applicability, and enforceability, making it a potentially mute instrument, as it has been the case in other FTAs.

\footnotetext{
${ }^{23}$ See Steffen Foss Hansen, Lars Carlsen \& Joel A. Tickner, Chemicals Regulation and Precaution: Does REACH Really Incorporate the Precautionary Principle, 10 ENVTL. SCI. \& PoL'Y 395, 404 (2007); Luján \& Todt, supra note 10; Lucas Bergkamp \& Lawrence Kogan, Trade, the Precautionary Principle, and Post-Modern Regulatory Process, 4 EUR. J. RISK REG. 493, 507 (2013).

${ }^{24}$ See Hansen, Carlsen \& Tickner, supra note 23; see also Luján \& Todt, supra note 10.

${ }^{25}$ See Hansen, Carlsen \& Tickner, supra note 23; Luján \& Todt, supra note 10.
} 


\section{How to Evaluate Costs and Benefits of Regulation?}

The second important substantive tool that will impact the way in which we apply precaution in Europe is the cost benefit analysis. Why? As already mentioned, in line with the Commission's Communication of 2000, the assessment of costs and benefits of regulation is part of the application of the precautionary principle. ${ }^{26}$ This cost benefit analysis will take place not only at the level of designing a legislative framework, but also at the level of implementation in particular instances.

This can be illustrated through the example of REACH. In the individual phase of authorization, individuals seeking the registration or authorization of chemicals can use cost benefit analysis to justify the potential risk of hazardous substances by the scale of the social and economic benefits of the use. More importantly, the use of cost benefit analysis in REACH takes place when evaluating whether a certain substance will be designated for the candidate lists, or included in the Annex of substances of a very high concern. These latter chemicals then, in turn, require a more elaborate justification for production/import and more elaborate risk assessment by the applicants. While remaining embedded in REACH's precautionary legislative framework, the way the cost benefit is conducted may have a significant impact on how the weight of risks-potential benefits-and costs to society is set. ${ }^{27}$

The cost-benefit assessment is not new in the EU legal order. In fact, the valuation of costs and benefits is an inherent part of any instrumentally rational action. ${ }^{28}$ Balancing of costs and benefits, as balancing interests and values, has always been an integral part of lawmaking. The TTIP may create conditions for strengthening the dominance of a particular sort of cost benefit analysis, the one that has been overwhelmingly practiced in the US for many years: Neoclassical welfare economics cost benefit analysis-CBA. ${ }^{29}$ This would have farreaching consequences for regulation in the EU.

\footnotetext{
${ }^{26}$ Eur. Comm'n, supra note 7.

${ }^{27}$ See Kenneth J. Arrow et al., Is There a Role for Benefit-Cost Analysis in Environmental, Health, and Safety Regulation?, 272 SCI. 221, 222 (1996). For instance, within the context of US chemical law (TSCA), only a few substances have been phased out in its almost 40 years of existence. This also includes asbestos, which was finally phased out after several judicial reversals (on the grounds of lack of "sound scientific evidence") only at the end of 90 s.

${ }^{28}$ See MAX WeBer, 1 ECONOMY AND SOCIETy (2003); Oliver Williamson, The Economics of Organization: The Transaction Cost Approach, 87 AM. J. OF SOc. (1978).

${ }^{29}$ See Frank Ackerman \& Lisa Heinzerling, Pricing the Priceless: Cost-Benefit Analysis of Environmental Protection, 150 U. PA. L. REV. 5 (2002).
} 
The EU has never adhered to the neoclassical welfare economics cost benefit analysis in the past-which is, from the US regulatory perspective, perhaps rather unprincipled or fuzzy. ${ }^{30}$ Yet, the question should be rather why, and possibly when, the welfare economics cost benefit analysis is a useful tool in the regulatory process. This is even more so since the welfare economics CBA not only attributes valuations, but also implies normative guidance-an ultimate factual prescription on which policy should be tailored. ${ }^{31}$

There are several reasons why the EU has never adhered to neoclassical welfare cost benefit analysis. First of all, the reasons are ideological-the differences encapsulating many issues from the concept of freedom to the role of the state in the economy. Second, the Commission has started playing with the idea of cost benefit analysis only quite late in comparison to the US- also importing from the US the awareness of the inherent limitations of this methodology. Third, the proportionality principle as practiced in the EU may have occupied an equivalent central role, as Susan Rose Ackerman argues. ${ }^{32}$ The proportionality principle has always required "sober" valuation of costs and benefits, in quantitative and qualitative terms, without restricting itself to the welfare economics CBA. ${ }^{33}$ Finally, the introduction of the precautionary principle in the EU treaties may have made it more difficult to advance the welfare economics CBA. For all of these reasons, the EU exercise called "valuation of costs and benefits" has maintained a pluralistic set of economic methodologies for quantitative valuations, and has included qualitative assessments ${ }^{34}$ where quantitative valuations of social or environmental concerns are inadequate.

Thus, the question becomes one of determining what the European Commission is advancing in its position paper when it calls for the approximation of economic assumptions within the framework of the TTIP. ${ }^{35}$ To be clear, the CBA has taken a powerful place in the US regulatory framework. The main advocates of this method praise the rationality of decision-making based on the CBA as well as the limitation of the abuses of state power,

\footnotetext{
${ }^{30}$ See Lucas Bergkamp \& Lawrence Kogan, Trade, the Precautionary Principle, and Post-Modern Regulatory Process, 4 EUR. J. RISK REG. 493, 507 (2013).

${ }^{31}$ See Susan Rose-Ackerman, Precaution, Proportionality, and Cost/Benefit Analysis: False Analogies, 4 EUR. J. RISK REG. 281 (2013); See Ackerman \& Heinzerling, supra note 29.

32 See Rose-Ackerman, supra note 31.

${ }^{33}$ See id.

34 Eur. Comm'n, Better Regulation "Toolbox" (June 25, 2015), http://ec.europa.eu/smartregulation/guidelines/toc_tool_en.htm. The Commission, in its last guidelines, while still acknowledging this fundamental problem of cost benefit analysis provides a large tool-kit to estimate such monetary values.
}

35 See Textual Proposal of the European Commission on TTIP Initial Provisions for Chapter on Regulatory Cooperation, art. 7(3)(b) (May 4, 2015). 
etc. ${ }^{36}$ The critiques of the welfare economics CBA in contrast suggest, for instance, that the CBA ascribes ultimately rather speculative values to costs and benefits of regulation, ${ }^{37}$ or that it discounts the future benefits for the present costs, contributing to inter-generational injustice. ${ }^{38}$

More relevant for our purposes, though, is the normative assumptions behind this method, which stand in stark contrast with the precautionary logic. The CBA method stands on the premise that a) values can be expressed on a monetary scale as individualized market preferences, b) the best policy is the one which is the most efficient-the one in which benefits outweigh costs, and c) the efficiency principle is insensitive to distributional effects-who incurs benefits and who incurs costs (Kaldor-Hicks efficiency). ${ }^{39}$

All of these premises are difficult to square with the way in which the precautionary principle is operationalized in Europe. First of all, the precautionary principle is concerned with how societies deal with uncertain risks and hazards, in a situation where we know little about the outcomes-including catastrophic risk-or probabilities. The welfare economics CBA assumes to know too much about the outcomes and probabilities-in order to establish costs and benefits. ${ }^{40}$ It may well be a viable tool to count costs and benefits of very well established risks in terms of outcomes and probabilities-but this is a sphere in which the precautionary principle has less relevance.

Second, CBA places the analysis in a normative framework, which places efficiency first. The question behind the CBA analysis is which solutions create most benefits with as little as possible cost. The preference for efficiency is at odds with precautionary principle, which takes as a starting point the plurality of values and interests, which need to be balanced.

\footnotetext{
${ }^{36}$ See Sunstein, supra note 9.

${ }^{37}$ See Ackerman \& Heinzerling, supra note 29; Duncan Kennedy, Cost-Benefit Analysis of Entitlement Problems: A Critique, 28 STAN. L. REV. 387 (1981).

${ }^{38}$ An additional important feature that distinguishes the US from the EU system is the possibility to enforce their version of better regulation in courts. The US courts have been eager to enforce a strict standard of review with regard to scientific evidence that need to be met by any regulator who wants to regulate. See Vogel, supra note 8. The standards for the engagement with stakeholders need to be met as well. See Wendy Wagner, Administrative Law, Filter Failure, and Information Capture, 59 DUKE L.J. 1321 (2010) (causing a significant regulatory chill). Usually it has been enough that the industry threatens with court action for regulators to water down the proposal. Id. The EU experience has been different, whereby the courts have both endorsed precautionary principle (EU treaties, case law) as well as given some deference to administration to assess what is the right way to implement it. Vogel, supra note 8.

${ }^{39}$ See Rose-Ackerman, supra note 31.

${ }^{40}$ The operationalization of this principle works, then, by attributing values trying to establish how much people are ready to pay or would be ready to pay for certain non-market goods, such as environmental safety or nature. These revealed preferences are aggregated in two forms as willingness to pay or willingness to accept, both without factoring in distributional concerns such as capability to pay.
} 
Equally, the precautionary principle is concerned with redistribution of the costs of business activity. While the businesses have the greatest benefits from introducing certain, potentially risky, substances into the market, it is the society, or environment, which carries the costs in terms of health or environmental standards. Another way of expressing this is to endorse the principle 'polluter pays.'

Finally, the PP is concerned with the impact of our activities over time, and possibly over prolonged periods of time. Yet, the metric of the CBA is characterized by discounting the future benefits to society of preserving ecosystems or healthy populations. It places more value on current costs to business than future benefits to society, and it justifies this approach by analogy to the trickledown effect re-oriented toward the future. ${ }^{41}$

Against this background, the pressure of the TTIP to approximate the economic assumptions and methodologies used in the field of impact assessment and CBA needs to be understood as oriented more toward re-aligning normative assumptions between the two jurisdictions (such as those outline above) rather than at any cognitive gains of the regulators. In fact, disagreement over the way cost benefit is conducted already runs deep through the European Commission's services. Thus, while the Secretariat General favors the US-like CBA-which is also due to the regular and intensive contact with the OIRA ${ }^{42}$ - the Commission's Directorates General (DGs) have preferred multiple criteria analysis. ${ }^{43}$

It should be clear by this point that the different approaches between the EU and the US do not relate to the lack of knowledge of either state party as to the principles or practice of various methodologies. Rather, these are based on the different normative assumptions and purposes pursued by regulators, and hinge on the different political ideologies in the US as well as in the EU.

An important EU internal political cleavage, which seems to coincide with the TTIP agenda, is the so called "Better Regulation" agenda, also known as "evidence based decision-

\footnotetext{
${ }^{41}$ See Frank Ackerman \& Lisa Heinzerling, Priceless: On KnOWing the Price of EVerything AND the Value of Nothing (2005).

42 See Andrea Renda, Too Good to Be True? A Quick Assessment of the European Commission's New Better Regulation Package, A Quick Assessment of the European Commission's New Better Regulation Package, CEPS SPECIAL REPORT NO. 108 (2015).

${ }^{43}$ See Andrea Renda et Al., AsSessing the Costs And Benefits of Regulation, EConomisti AsSOCIATI, Study for the Eur. COMM'N (2013), http://www.economistiassociati.com/files/cba_study_sg_final_0.pdf. The multiple criteria analysis distinguishes between various objectives and groups affected by regulation, thus giving more space for considering distributive consequences or other normative concerns along with efficiency.
} 
making," "Regulatory Fitness," or "Smart Regulation." 44 These policy initiatives have been developed in a political climate increasingly concerned with the excessive regulatory burden-or red tape-imposed on business and, in particular, aimed to reduce regulatory burdens placed on small businesses. ${ }^{45}$

The anti-red tape political agenda has taken on prime importance within the Juncker's Commission, which has made it-politically-one of its main goals. The efforts have resulted in the new May 2015 guidelines, ${ }^{46}$ which contain several important innovations:

1) Two stage impact assessment and stakeholder consultation. Regulatory initiatives will be subject-depending on the importance of the intended regulation-to a two-stage impact assessment and a two-stage consultation procedure: Inception impact assessment should be accompanied by initial consultations, in order to determine the proper framing of the problem and methodologies to address it. If the regulatory idea is to take off, a full impact assessment should be developed, accompanied by a second, public, consultation.

2) Cost benefit analysis. The new guidelines set rules on how to conduct cost benefit analyses. While at several points the Commission admits that certain values are difficult to quantify-for instance those related to fairness, redistribution or valuation of human life-the guidelines at the same time provide very specific instructions regarding how to monetize those otherwise unquantifiable concerns-life, environment, etc. ${ }^{47}$ It is rather puzzling that the better regulation guidelines provide tools to do what is claimed to be impossible.

3) Regulatory Scrutiny Board. The new guidelines also introduce a Regulatory Scrutiny Board, which is to replace the Impact Assessment Body. The difference between the old and the new incarnation of this body is that the new body, which is not far from the US

\footnotetext{
44 Eur. Comm'n, Commissionaires (2014), https://ec.europa.eu/commission/2014-2019/timmermans_en. Currently, this is the agenda of one of the most prominent vice-president of the European Commission-Mr. Timmermans.

${ }^{45}$ See Jean-Claude Juncker, A New Start for Europe: My Agenda for Jobs, Growth, Fairness and Democratic Change, at 5-6, 18 (July 15, 2014).

46 See Eur. Comm'n, Better Regulation Guidelines (2015), http://ec.europa.eu/smartregulation/guidelines/docs/br_toolbox_en.pdf.

${ }^{47}$ See id. For instance, the 'quality-adjusted life year' matrix is placed under the rubric of non-monetary valuations, because they concern years saved instead of money saved. Yet the value of years is calculated in monetary terms. The usefulness of the regulation-its benefits-are given monetary value which is correlated to how many years of life the regulation will save: the younger the person saved, the more money will be saved, and the more efficient the regulation is.
} 
OIRA, becomes a permanent organ with a right to veto all of the Commission's proposals that are not in line with the better regulation standards.

The interaction-and eventual cross-membership-with RCB may be of special importance in the context of the TTIP. In particular, this body could become of the last resort institution to enforce the recommendations of the RCB with regard to the issues belonging to its jurisdictions-such as the use of science or a proper cost benefit analysis - in a case that particular DGs in the European Commission do not follow such recommendations.

4) Surveying regulatory fitness. The fitness of regulation will not only be tested a priori but also a posteriori. The testing will be undertaken by the Regulatory Scrutiny Board, as a matter of regulatory practice as well as on the proposal of stakeholders-independent ones or coming from the REFIT stakeholder group-and it may result in the assessment and removal of unnecessarily burdensome regulatory measures. Several commentators have linked the regulatory fitness exercises to the ongoing negotiations of TTIP measures, whereby several proposed regulations-such as EU Fuel Quality Directive, or the DG Environment proposal to phase out endocrine disruptive chemicals in pesticides-have been withdrawn or significantly delayed in relation to TTIP negotiations. ${ }^{48}$

Some commentators have noticed that the shift toward decision-making based on evidence and better regulation after 2002 may be seen as an approximation with the American regulatory culture. ${ }^{49}$ Despite this shift, several forces have counteracted a close alignment of the EU with the US regulatory culture. The combination of the EU multi-level structure with different political preferences among some national politicians, ${ }^{50}$ persistently higher public salience of regulation, ${ }^{51}$ the preference for integrated evaluations of costs and benefits of regulation by many Commission $\mathrm{DGs},{ }^{52}$ and finally, the constitutional

\footnotetext{
48 See Ferdi De Ville \& Gabriel Siles-BrÜgge, TTIP: The Truth about the Transatlantic Trade And InVESTMENT PARTNERShiP (2015).

49 See Anne CM Meuwese, EU-US Horizontal Regulatory Cooperation: Mutual Recognition of Impact Assessment?, in Transatlantic Regulatory Cooperation: The Shifting Roles of the EU, the US and California 249 (David Vogel \& David Swinnen eds., 2011).

${ }^{50}$ See Vogel, supra note 8.

${ }^{51}$ See id.

52 See Renda, supra note 42; Cavan O'Connor Close \& Dominic J. Mancini, Comparison of US and European Commission Guidelines on Regulatory Impact Assessment/analysis, INDUS. POL'Y \& ECON. REFORMS PAPERS NO. 3 (European Commission, Enterprise and Industry Directorate General 2007), https://infoeuropa.eurocid.pt/files/database/000047001-000048000/000047484.pdf.
} 
commitment of the EU to the precautionary principle, ${ }^{53}$ have contributed to shielding the European way of regulating. Yet the TTIP may nonetheless tip the balance in the opposite direction.

The TTIP institutions will likely reinforce the internal political commitments of the current Commission, which could be a major impetus to push the EU toward the US regulatory culture. Internally, the Better Regulation Package gives an important argumentative advantage to the Commission's Secretariat General vis-à-vis particular Commission's DGs insofar as the Secretariat General has prioritized standardized welfare economics CBA-as opposed to integrated CBA. This effect is likely to be strengthened by the increased powers of the Regulatory Scrutiny Board, which has already proven more zealous than the previous Impact Assessment Board. ${ }^{54}$

\section{Shifting Roles in International Standardization}

The TTIP stresses the role of international standards for the approximation of the regulation on both sides of Atlantic. Moreover, it requests state parties to present joint proposals to the international standardization bodies. While there are a large number of standardization bodies, dealing with various kinds of subject matter, any generalization as to the legitimacy levels or the strictness of standards of protection is very difficult.

Yet two general and related observations can be made regarding to the future of PP in Europe. First, along with various legitimacy concerns raised with regard to international standardization, ${ }^{55}$ the international standardization bodies would likely set lower standards than those found in the EU because a lowest common denominator among many countries has to be found. For example, Codex Alimentarius consistently sets considerably higher levels of permissible pesticide residues on vegetables than the EU. ${ }^{56}$ The same body simultaneously requires considerable lower levels of residue than the US.

\footnotetext{
${ }^{53}$ See Rose-Ackerman, supra note 31.

54 See Impact Assessment Board / Regulatory Scrutiny Board, 2015 Activity Statistics (2016), http://ec.europa.eu/smart-regulation/impact/key_docs/docs/iab_rsb_stats_2015.pdf.

55 See Anna Aseeva, Global Good Process Standards and World Trade Law: A Study of Norms and Normativity in Global Law and Governance Perspective (2015) (unpublished manuscript) (on file with author).

56 See Centre for Int'l Envtl. Law Report, Lowest Common Denominator 11 (Jan. 7, 2015), http://www.ciel.org/lowest-common-denominator/ (last visited June 18, 2017). For illustration, I reproduce here the table concerning the levels of permitted residue for apples, carrots and cabbage. The first number indicates the US permitted levels, the second Codex Alimentarius permitted levels, and the third number indicates the EU permitted levels, in comparable units (usually in $\mathrm{mg}$ ).
}

Apple (Captan 25.0 / 15.0 / 3.00, Clothianidin 1.00 / 0.40 / 0.40, Diazinon 0.50 / 0.30 / 0.01, Diphenylamine 10.0 / 10.0 / 0.01, Malathion 8.00 / 0.05 / 0.02, Methomyl 1.00 / 0.03 / 0.02 , Tebuconazole 0.05 / 1.00 / 0.30, Ziram 7.00 / 5.00 / 0.10). 
Second, the requirement in the Treaty that the EU and the US should take a common position in these international fora may exacerbate some of the legitimacy challenges that these fora already suffer from. In particular, if the EU and the US may have previously had differing positions, also depending on their level of precautionary consciousness, the demand of the TTIP to elaborate common positions may lower the contestation of knowledge and, thus, of standards in these bodies. Such a lowering of standards is problematic both in terms of the growing joint power of the US and the EU in these bodies, possibly at the expense of developing countries, and in terms of the epistemic quality of the debate, which may fail to discover possible biases and errors in knowledge that underpin proposed standards.

\section{The Institutional Context of the Precautionary Principle}

In the previous sections, I explained the differences between the positions taken by the EU and the US, suggesting that proposed exchanges in the RC are more concerned with aligning normative positions than achieving cognitive gains. In this part of the Article, I will discuss the proposed TTIP's institutional arrangements, which appear to be aimed at aligning the two regulatory cultures. In other words, exchange and learning in the context of the TTIP will be placed in a specific institutional environment, which sets the rules of the exchange and which ultimately exerts pressure on what can be learned within them.

\section{Bilateral Mechanism ${ }^{57}$}

Within the framework of the TTIP, the bilateral mechanism presents what may be called regular regulatory dialogue. This dialogue, concerning issues that have a significant impact on trade and investment, is envisaged to involve regulators and senior administrative officials from both sides of Atlantic. According to the EU proposal, the bilateral exchanges between regulators may start at any point in the regulatory cycle in reaction to a reasoned opinion of the counter-party to any issues of concern-often on the proposal of their stakeholders. The regular bilateral exchange may take place through meetings, exchange of documents, and in any other way the parties to the bilateral mechanism find appropriate.

Carrot (Deltamethrin 0.20 / 0.02* / 0.05, Difenoconazole 0.50 / 0.20 / 0.40, Iprodione 5.00 $/ 10.0 / 0.50$, Mancozeb $1.00 / 1.00 / 0.20$ )

Cabbage (Carbaryl $21.00-0.01$, Fluopicolide 5.00 / 7.00 / 0.20, Glyphosate $0.20-0.10$, Mancozeb 9.00 / 5.00 / 3.00, Metalaxyl 1.00 / 0.50 / 1.00, Novaluron 0.50 / 0.70 / 0.01, Permethrin $6.00 / 5.00 / 0.05)$. The table is based on the information provided by the United States Department of Agriculture Foreign Agricultural Service, FAS Online, International Maximum Residue Level Database.

${ }^{57}$ See Eur. Comm'n, supra note 35, at art. 8-12. 
Once implemented, the bilateral exchange mechanism offers a space where regulators can demand explanations and justifications from their counterparty with regard to proposed regulation. They may demand, in particular, justification if proposed regulation diverges from US/EU adopted or proposed regulation, request justification concerning the diverging methodologies used, the use of knowledge and economic assumptions, and engage in exchange that aims to ensure consistency between these assumptions. The questions that may be raised in this dialogue have a direct connection to those linked to the application of the precautionary principle, such as the level of proof necessary to show harm as to nature/health, the validity of scientific studies, the possibility of monetizing certain benefits such as nature or human health, the level of risk/hazard that trigger the application the precautionary principle, or the "proper" role of alternative forms of valuations of costs and benefits-such as qualitative or multiple criteria analysis.

There are at least three reasons why we may view the bilateral mechanism as contrary to precautionary thinking. First, the TTIP has as its normative objective the facilitation of transatlantic trade and investment. As noted by many commentators, this normative objective will shape the discursive environment and provide a vocabulary to articulate problems and solutions in the TTIP's institutions. ${ }^{58}$ There is a significant normative difference in framing, for instance, the prohibition of a certain chemical barrier to trade and a reason for concern, as opposed to a measure that seeks to maximize public health. Yet, even if in the TTIP bilateral exchange takes place between the respective environmental regulators, DG Environment and the US Environmental Protection Agency, this debate would be structured in terms of trade, and likely would require a significant input from trade representatives.

Second, the EU's political commitment to cutting red tape will exert another level of pressure on regulators when proposing certain measures-both within the TTIP context and the Better Regulation context. Finally, the third important factor is the enhanced role of stakeholders. Stakeholders will be major agenda-setters in the in the TTIP framework, which gives a 'competitive advantage' in terms of participation to the best-resourced stakeholders.

Bilateral exchange remains, nevertheless, an ad hoc mechanism. Even if the exchange will be coordinated by the more centralized institutions-as I will discuss in the following section-it will be led at least in principle by sector-specific regulators, who often endorse non-trade normative concerns, such as the protection of the environment or public health. More institutionalized committees have a very different agenda in this regard.

\footnotetext{
58 See Christiane Gerstetter et al., Regulatory Cooperation under TTIP-A Risk for Democracy and National Regulation?, HEINRICH BÖLL STIFTUNG TTIP SERIES (2014); Marija Bartl, Internal Market Rationality, Private Law and the Direction of the Union: Resuscitating the Market as the Object of the Political, 21 EUR. L.J. 572 (2015).
} 


\section{Institutional Mechanism ${ }^{59}$}

Until very recently, the Commission's "crown" institution of the RC was the Regulatory Cooperation Body (RCB), tasked with the monitoring, implementing and setting an agendathe so called Annual Regulatory Cooperation Programme. Met with hesitance on the US side, the Commission's March position paper (March papers) ${ }^{60}$ discusses this body only in general outline and under a not very inspiring nomenclature as the Institutional Mechanism (IM). The Commission has promised to publish a new position paper on this matter. ${ }^{61}$

While the level of clarity has only decreased in the March papers, a few important issues remain constant. Whatever the name the institution will obtain, it seems that both trading partners envisage a mechanism that will, at a minimum, publish an Annual Regulatory Cooperation Programme, coordinate bilateral exchanges, and monitor the implementation of the agreement. Second, the composition of the IM seems to follow the one proposed for the RCB. The RCB's composition was as follows:

The RCB shall be composed of representatives of the Parties, including at the non-central level. It shall include senior representatives of regulators and competent authorities, as well [as] representatives responsible for regulatory coordination activities and international trade matters at the central level. In addition, whenever the RCB considers cooperation in relation to specific regulatory acts at central or non-central level, the relevant regulators and competent authorities responsible for those acts shall be invited to participate in RCB meetings. ${ }^{62}$

The March papers show a noticeable continuity. Even if they do not discuss the composition of the IM separately, they do outline it in the discussion regarding the joint ministerial body: "Ministerial meetings will be prepared through a process that ensures full participation and involvement by the relevant regulatory authorities concerned, senior officials responsible

\footnotetext{
${ }^{59}$ See Eur. Comm'n, supra note 35, arts. 14-16.

60 Eur. Comm'n, TTIP-EU Proposal for Chapter: Regulatory Cooperation (Mar. 21, 2016), http://trade.ec.europa.eu/doclib/docs/2016/march/tradoc_154377.pdf.

${ }^{61}$ See id. at 9.

62 Eur. Comm'n, TTIP Initial Provisions for CHAPTER on Regulatory Cooperation, art. 16 (May 4, 2015) http://trade.ec.europa.eu/doclib/docs/2015/april/tradoc_153403.pdf.
} 
for the implementation of TTIP and the authorities responsible for coordination of regulatory policies in both parties." 63

Both documents single out trade officials, on the one hand, and regulatory affairs officials ${ }^{64}$ on the other: The officials who clearly possess a more "general" competence over the matters dealt with by the TTIP. It is those officials who will most likely take up a more permanent role in the institutional body. Other relevant regulatory authorities, if the body is to maintain operational capacity, will likely participate on a rotational basis-depending on the issue discussed.

This institutional arrangement opens up a plethora of questions regarding its regulatory implications: Its agenda-setting role-what policies will be viewed as "worthy" of pursuingthe type of bilateral cooperation encouraged, and, finally, what influences it will have on bilateral exchanges.

First, it is important to note that the permanent members of this body all share a similar cognitive framing of the world as a market. In this world, the harmony is interrupted by various barriers: Either barriers to trade or unnecessary regulation-red tape-both of which need to be removed in order to restore its harmony. We can expect certain level of mutual understanding between these officials - whether they come from the EU or the USas to language and problems that need to be addressed.

Second, the division between permanent and non-permanent members creates problems of its own. Thus, if trade and regulatory affairs officials have more opportunities to socialize together, discussing in common all those environmental and public health regulationswhile officials from other departments who come and go-they will be more likely to grow more fond of each other, ${ }^{65}$ reinforcing a pre-existing congruence due to their shared cognitive frameworks.

\footnotetext{
${ }^{63}$ See Eur. Comm'n, supra note 60, at annex.

${ }^{64}$ See Eur. Comm'n, supra note 62. By regulatory affairs officials, I mean those members of the governments who are responsible for what is called by the European Commission "regulatory analytics." This includes the administration of impact assessments, and regulation review. In the US, these are the representatives of the Office of Regulatory Affairs (OIRA) and in Europe, the members of the Secretariat General of the European Commission. The co-operation among those officials has already been taking place for years.

${ }^{65}$ See Daniel Carpenter \& David A. Moss, Preventing Regulatory Capture: SpeCial Interest Influence and How to Limit IT (Cambridge University Press 2013); James Kwak, Cultural Capture and the Financial Crisis, in Preventing REGULATORY CAPTURE, (Daniel Carpenter \& David A. Moss eds., 2013); Andrew Baker, Restraining Regulatory Capture? Anglo-America, Crisis Politics and Trajectories of Change in Global Financial Governance, 86 INT'L AfFAIRS 647 (2010).
} 
As a result, the aggregate power of these regulators, in whatever body ultimately emerges, will determine the meaning of exchange and learning in the RC. ${ }^{66}$ In contrast, more incidental, issue-specific officials, who are also the main carriers of non-market normative concerns, will be in a far less advantageous position when defending putative barriers to trade.

\section{Sectoral Committees}

In the unlikely event that an institutional mechanism will not be created, the TTIP negotiators seem to be developing a set of similar regulatory institutions, but that are restricted by sector. An important committee for the implementation of precautionary principle in Europe can be found in the Chapter on Sanitary and Phytosanitary Measures. ${ }^{67}$ In particular, in recently leaked documents, even if there are still disagreements as to the wording, both trade partners expressed their preferences as to the basic composition of this committee:

[EU: The Parties hereby establish a Joint Management Committee (JMC) for SPS Measures, hereafter called the Committee, compromising regulatory and trade representatives of each Party who have responsibility for SPS measures.]

[US: The Parties hereby establish a Committee on Sanitary and Phytosanitary Matters (the "Committee") compromising representatives of each Party..... Each Party shall ensure that its representatives on the Committee are the appropriate officials from its relevant trade agencies or ministries and competent authorities with responsibility for the development, implementation, and enforcement of SPS measures. $]^{68}$

Moreover, the US appears intent on going much further in its institutional design, namely, it believes that this committee should possess more formal decision-making power. To be precise, according to the US proposal the committee would be able to reject or modify measures submitted to it by either party. In a case of such a negative opinion, the parties

${ }^{66}$ Compare Martti Koskenniemi, The Politics of International Law-20 Years Later, 20 EUR. J. INT'L L. 7 (2009), with Andrew T.F. Lang, Legal Regimes and Professional Knowledges: The Internal Politics of Regime Definition (Margaret A. Young ed., 2012).

${ }^{67}$ Greenpeace, Eur. Comm'n: Chapter on Sanitary and Phytosanitary Measures, Consolidated Proposals, art. X 15 (2016), https://ttip-leaks.org/andromache/doc11.pdf.

$68 / d$. 
would be able to reverse it only if complying with higher justificatory obligation. ${ }^{69}$ The US also proposes a "Working Group on Trade in Products of Modern Agricultural Technologies" to discuss issues relevant to the biotech industry-including, most notably, issues related to genetic modification. Additionally, this group would be co-chaired by representatives of each party's trade agency. ${ }^{70}$ Finally, the US proposes standing technical working groups to resolve disputes regarding the applicable science and understanding of the relevant risks in animal health, plant health and food safety. ${ }^{71}$ Even if the European Commission has not accepted these proposals, its position is not too remote: The Commission accepts the need for technical consultation in the case of divergent opinions between the two parties. ${ }^{72}$

Whatever the ultimate shape of this committee, or its technical working groups, trade officials and regulatory affairs officials will be overwhelmingly and permanently represented. Thus, this raises a very similar series of concerns to the concerns discussed in relation to the IM. Moreover, in the context of this chapter the direct engagement of trade officials and regulatory affairs officials with science is unequivocally directed at the alignment in use of science, rather than an inquiry into its merits.

Ultimately, the de-regulatory effect of the TTIP's institutional structures-bilateral exchange, IM and sectoral committees-may be further reinforced due to the increased role of stakeholders in the TTIP. Stakeholder have significant agenda-setting powers and consultative functions in the framework of the proposed agreement. Nevertheless, this does not give the same advantages to all stakeholders. Proposals aimed at a higher level of, for instance, environmental protection are structurally disadvantaged in the context of the TTIP. A first obvious reason for this structural disadvantage is that businesses have more resources, which allows them to make themselves better represented viz other stakeholders in the regulatory process. ${ }^{73} \mathrm{~A}$ second reason would be the dominance of trade officials and regulatory affairs officials in the TTIP institutions is likely to be allied to the ideological battle against red tape and barriers to trade, both of which are portrayed as impediments to economic growth. This is, once more, to the advantage of business stakeholders. Finally, and rather paradoxically, de-regulatory pressures arise additionally because of the limited legal

\footnotetext{
${ }^{69}$ See id. art. X 5, para. 6.

${ }^{70}$ See id. at US art. X 12, para. 8.

${ }^{71}$ See id. at US art. X 16.

${ }^{72}$ See id. at EU art. X 17.

${ }^{73}$ See Wagner, supra note 38; Baker, supra note 65; Maria Green Cowles, The Transatlantic Business Dialogue and Domestic Business-Government Relations, in TRANSFORMING EUROPE: EUROPEANIZATION AND DOMESTIC CHANGE (Maria Green Cowles, James Caporaso \& Thomas Risse eds., 2001); Beate Kohler-Koch, Governing with the European Civil Society, in DE-MYSTIFICATION OF PARTICIPATORY DEMOCRACY: EU GOVERNANCE AND CIVIL SOCIETY 105 (Beate Kohler-Koch \& Christine Quittikat eds., 2013).
} 
effects attributed to RC. ${ }^{74}$ Given that the TTIP institutions will have no formal legal power, except for the ISDS, the members of these bodies are likely to favor those recommendations that may be implemented without requiring many formalities, without the involvement of legislators, and that can be easily monitored. Thus, it is likely that these institutions will decide, more often than not, that certain regulations should not be adopted rather than taking positive action. This can take place through the implementation of cost-benefit analyses or the use of science-e.g. standards of proof-as outlined in section C of this Article.

\section{E. Conclusion}

The European Commission assures us that the TTIP's RC will not impact the operation of the precautionary principle in Europe, because it cannot change the legislative framework of measures such as REACH. Yet, as I have attempted to demonstrate, the TTIP institutions can still influence the implementation of regulations, even if they cannot change framework legislation itself. These institutions can, for instance, have an impact on which items will be placed on the lists of substances of high concern in the REACH's Annex by advocating a narrow version of CBA, or demanding that authorities supply a different standard of scientific proof.

Beyond per se implementation, the RC will impact the future of a broader interpretation of precautionary regulation owing to several factors. An extensive exchange and consultation-with the counterparty, its trade officials, regulatory affairs officials and, last but not least, stakeholders - should take place as to a majority of proposed new measures, as well as to the review of existing measures. The number of issues for which a justifications are due will increase in the RC, while the exchange will take place in an institutional setting that both allocates incentives and opportunities unevenly and covertly re-distributes power among and within existing institutions.

The TTIP will impact inter-institutional balance in the EU at different levels. It will re-balance regulatory power between various DGs within the EU Commission. For instance, the TTIP will result in a shift in power from particular Commission DGs to the General Secretariat, as well as a shift from environmental or social DGs toward DG trade. This is the case both at the level of composition of bodies and at the level of the substance of policies. Furthermore, the focus of the TTIP's regulatory cooperation on the very early stages of the regulatory process - before any proposal from the Commission sees the light of day-will constrain the extent to which democratic legislators can influence the content of a regulation in the EU and, thus, preempt the desired level of precaution. Equally, what promises to be a

\footnotetext{
74 See Fritz W. Scharpf, The Asymmetry of European Integration, or Why the EU Cannot Be a "Social Market Economy", 8 SOCIO-ECON. REV. 211 (2009). This argument will sound familiar to European scholars. The lack of political capacity at the side of the EU political institutions has made the negative integration a main driver of the EU project, with ensuing problems and assymetries.
} 
patchwork of various sectoral committees, technical working groups, and consultative bodies will turn the TTIP into an accountability nightmare.

Notwithstanding the fact that the RC's conclusions, recommendations, and decisions will not have any binding force, that does not mean the RC is impotent. The TTIP changes the rules of the regulatory game by crucially altering, who must justify their policies to whom, when is a justification owed and, most importantly, what exactly is to be justified. Thus, we need to take it seriously. 
